\title{
Opinion
}

\section{Amyotrophic lateral sclerosis and herpes virus: A casual or causal association? Twelve years after}

Dear Editor, in 1998 we related a curious case of a casual or causal association of herpes virus and Amyotrophic Lateral Sclerosis ${ }^{1}$. Finishing the discussion we declared that we were responsible to communicate the patient's evolution. This letter is to inform how is going the patient twelve years after the first evaluation.

Since January 1997 we evaluated the patient sporadically (about five or six times); the last time in January 2009. When the patient went to renew the drive-license the doctor responsible for the examination send me back for opinion.

The patient is retired but is doing some works in his daughter's office. He is perfectly able to take care of him self. $\mathrm{He}$ is able to walk and there is a mild difficulty to climb steps. In the upper limbs it is very difficulty to use proximal muscles e normal force is seen in distal extremity. There is no difficulty to speak or to swallow and there are no other deficits.

Since the 1997 we have samples of cerebrospinal fluid, resumed in Table.

A new electricalmyography, performed in January 2007 , showed the confirmation of a chronic degenerative affection of the anterior horn of spinal cord proximal in upper and lower limbs; few signals of denervation point showed that the disease is chronic and slow progressing. When compared with the examination in january/1997 we observed worsening of all patterns, especially in proximal upper limbs.

The magnetic resonance imaging of cervical spine, performed in March 2007 showed a mild reduction of the spinal cord, with areas of hyper signal, especially in $\mathrm{C} 2$, C3 e C4 segments. There is an aspect of septations in epidural space, determining compression of the spinal fluid liquid in this space; the spinal lesion is suggestive of e mielomalatia.

We just want to communicate the evolution of this curious case; not to explain it.

\section{REFERENCE}

1. Ferri-de-Barros JE, Moreira M. Esclerose lateral amiotrófica e herpes vírus. Relato de um caso curioso: uma associação casual ou causal. Arq Neuropsiquiatr 1998:56:307-311.

\section{João Eliezer Ferri-de-Barros}

Marina Moreira

Clinical Neurology of UNITAU'S Medical Department

Avenida Anchieta 1281

12142-280 São José dos Campos SP - Brasil

E-mail: jferri@vivax.com.br

Table. Evolution of cerebrospinal fluid.

\begin{tabular}{lccccc}
\hline Date & Cells & Proteins & Gama & Elisa herpes 1 & Elisa herpes 2 \\
\hline Fev 1997 & $4.3 / \mathrm{mm}^{3}$ & $108 \mathrm{mg} / \mathrm{dL}$ & normal & $45 \mathrm{U}$ & $55 \mathrm{U}$ \\
May 2001 & $5.0 / \mathrm{mm}^{3}$ & $64 \mathrm{mg} / \mathrm{dL}$ & normal & $35 \mathrm{U}$ & $49 \mathrm{U}$ \\
Jan 2007 & $4.0 / \mathrm{mm}^{3}$ & $71 \mathrm{mg} / \mathrm{dL}$ & $17.6 \%$ & DO/cut-off: 13U & DO/cut-off: 13U \\
\hline
\end{tabular}

